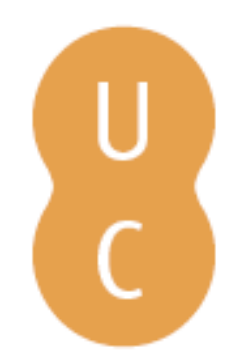

\title{
nombalina
}

\section{Belonging and place in the age of globalisation: the case of Swiss 'Heimat'}

\author{
Autor(es): Barkhoff, Juergen \\ Publicado por: Imprensa da Universidade de Coimbra \\ URL \\ persistente: URI:http://hdl.handle.net/10316.2/43213 \\ DOI: $\quad$ DOI:https://doi.org/10.14195/978-989-26-1483-0_6
}

Accessed : $\quad$ 26-Apr-2023 06:11:09

A navegação consulta e descarregamento dos títulos inseridos nas Bibliotecas Digitais UC Digitalis, UC Pombalina e UC Impactum, pressupõem a aceitação plena e sem reservas dos Termos e Condições de Uso destas Bibliotecas Digitais, disponíveis em https://digitalis.uc.pt/pt-pt/termos.

Conforme exposto nos referidos Termos e Condições de Uso, o descarregamento de títulos de acesso restrito requer uma licença válida de autorização devendo o utilizador aceder ao(s) documento(s) a partir de um endereço de IP da instituição detentora da supramencionada licença.

Ao utilizador é apenas permitido o descarregamento para uso pessoal, pelo que o emprego do(s) título(s) descarregado(s) para outro fim, designadamente comercial, carece de autorização do respetivo autor ou editor da obra.

Na medida em que todas as obras da UC Digitalis se encontram protegidas pelo Código do Direito de Autor e Direitos Conexos e demais legislação aplicável, toda a cópia, parcial ou total, deste documento, nos casos em que é legalmente admitida, deverá conter ou fazer-se acompanhar por este aviso.

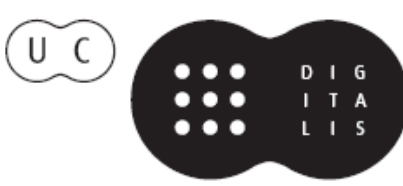




\section{IDENTITY(IES) A MULTICULTURAL AND MULTIDISCIPLINARY APPROACH}

\section{ANA PAULA ARNAUT \\ (ORG.)}

IMPRENSA DA UNIVERSIDADE DE COIMBRA

COIMBRA UNIVERSITY PRESS 


\title{
BELONGING AND PLACE IN THE AGE OF GLOBALISATION. THE CASE OF SWISS HEIMAT
}

Juergen Barkhoff

Trinity College Dublin

\begin{abstract}
One of the most important and least understood cultural effects of globalisation might well be the weakening of the relationship between place and identity. This article draws on recent cultural theories of globalisation and explores the impact of globalisation on the specific traditon of Heimat in the German speaking world; a concept which posits, since the late $19^{\text {th }}$ century, a particularly strong link between personal biography and cultural memory of place and between rootedness in place and identity. The article examines how increased mobility and global connectivity impact on our sense of place and what consequences that might have on notions such as belonging, citizenship or agency. The lecture draws on examples of cultural and literary narratives of rootedness, migration, displacement and reembedding in German speaking Switzerland. It contrasts the work of Thomas Hürlimann, a Swiss writer who analysis critically the fundamental changes the forces of globalisation have brought upon his homeplace in the centre of Switzerland in the Alps with that of transcultural writer Melinda Nadj Abonji, who
\end{abstract}


reflects in her semi-autobiographical writing her experience of migration from the Vojvodina in Serbia to Switzerland as a living between cultures and as the painful, but also enriching experience of loss of Heimat and the attempt to find or create a new homeplace.

Keywords: Globalisation, Belonging, Place, Cultural Identity, Swiss Literature

Globalisation, the "complex, accelerating, integrating process of global connectivity" (Tomlinson, 2007: 352) is clearly the most important and influential mega-trend of our time, and accordingly it is has been studied from many angles. Its cultural effects, and especially those influencing aspects of identity and self, are however far less well studied and understood than those relating to, for example, the economy, politics or society. One particularly important aspect in this is the question of how hyperconnectivity via electronic media and our increasingly mobile lives affect notions of place, belonging and settledness and weaken the relationship between communicative experience and the association of communities with place. As early as 1991, in his influential Consequences of Modernity, Anthony Giddens described these processes as a "disembedding" of the individual. Garcia Canclini in 1995 analysed the related phenomenon of „deterritorialisation“, and in an important contribution on cultural globalisation Tomlinson (2007) recently hypothesised that this weakening of the relationship between place and cultural identity might well be the most important long-term effect of globalisation.

Let me, as a cultural and literary historian of the German-speaking world, examine this topic with recourse to the specific German concept of Heimat. It is a distinct and untranslatable term for the 
special place that is a utopia as much as a past memory and place of longing; a term that connotes community, belonging, ease of orientation, acceptance (as long as you don't violate the norms too drastically) and rootedness in history, tradition and daily practice; a term especially loaded with significance, emotion, memory and expectation. It is what anthropologists call an 'anthropological place' (cf. Augé, 1995: 42 ff.), a place of relations, of history and of identity, a signifying space and and a universe of recognition. It is often the actual place of birth and that of family history and of the history of a community and a region. It is thus a place where personal and collective memories intertwine. In the following I will use this specific tradition of Heimat as a significant and symptomatic foil for my wider exploration of the role of place and belonging in the age of globalisation.

To begin this exploration let us briefly go back in time to the onset of our modernity at the end of the 18th and the beginning of the 19th century. "Wo gehen wir denn hin?"', Immer nach Hause. "Where are we going to?' 'Ever homewards"' (von Hardenberg, 1987: $164)^{44}$. In 1802 , at the onset of the modern age, the Romantic poet Friedrich von Hardenberg was already expressing the subtle but fundamental dialectic between increased mobility - the modern compulsion to be on the move both mentally and physically - and the longing for home as a place of origin and belonging. Hardenberg's nom de plume Novalis tellingly means 'new land, new territory': he sought, in the spirit of modernity, to conquer new frontiers in his thinking and writing. European Romanticism, for which he was a central early influence, was at the same time a sharp diagnosis of and a counter-movement to the unfolding dynamics of modernity around 1800. Novalis's dictum captures very well the conundrum that in an

${ }^{44}$ All translations from the German, with the exception of the Ernst Bloch quotation, are by the author. 
age increasingly dominated by mobile lives the question of where we come from and belong to does not become obsolete, but on the contrary comes into sharper focus then ever. Novalis also ingeniously captures the fact that this 'home', this place of an alluring "totality temptation" (to borrow Marc Augé's anthropological term, 1995: 48) is forever elusive. We are always, restlessly and endlessly, seeking it, moving towards it. This implies that we will never reach it, never be totally at home anywhere. With its elusive promise, however, home or Heimat holds a curious power over us. But does it still have a formative influence on identities? Anthony Elliott's research on the self in modernity has shown eloquently and persuasively that "in a highly mobile world, there are extensive and intricate connections between physical travel, new forms of communication and selfidentity. Mobilities restructure the deepest link between the personal and the global, selfhood and society" (Elliott, 2013: 178 f.). Allow me to take as starting point his summary observation, which draws on Zygmunt Bauman's diagnosis of liquid modernity:

Twenty-first-century society is a world [...] of light mobilities and liquid experiences, a world in which people, organizations, institutions, employment, entertainment, images, messages, money and the like are framed and positioned within global flows that undermine national, societal borders. This growing fluidity and liquidization of the social network carries serious implications for experiences of self, identity, interpersonal relationships and intimacy. (2000: 187)

Following on from this, Anthony Elliott asks the question that is pertinent to this investigation too: are the emerging new modes of identity "less tied to fixed localities, regular patterns or dwelt-in cultural traditions"? (2013: 181) 
It is certainly true that new mobilities and communication technologies bring about a growing deterritorialisation of communicative experience. If the term Heimat signifies an embedding within locality and its history and traditions, then globalisation clearly creates and accelerates processes of disembedding. Let us see whether we can shed some light on this dynamic by briefly examining the history of the Heimat discourse.

The Heimat metaphor frames questions of cultural identity principally in a spatial manner. It invites identifications via a spatial organisation which signals belonging, familiarity and reliability and thus evokes a concept of cultures as spatially secluded, homogenous and integrating identities (cf. Böhme, 2005: 602). It is important to remind ourselves of the origins of the discourse on Heimat in the late nineteenth century's movement of art and artisanship celebrating region and place. The invention of Heimat as a cultural topography that creates meaning, provides orientation and organises interaction was a culturally conservative reaction to the disorientating and often traumatic processes of modernisation during the so called Gründerzeit in the last three decades of the nineteenth century. It was a reaction to industrialisation and urbanisation as well as to the increasing mobility of migrant workers and the often uncomfortable or even threatening presence of new migrant communities. Against the threats of massification, anonymity, alienation and the presence of an unfamiliar 'other' it projected a protective, imaginative rural place which, being immune to the forces of modernity, offered a space of retreat where premodern ways of life and cohesive communities still existed. The duality that constructs this antithesis is familiar and still present in today's debates: rural versus urban, agrarian society versus industrial zones, small versus big, nature versus technology, local and regional versus national or supranational. The emotional and sentimental connotations of Heimat relate to these antitheses. Looking at the etymology of Heimat we can also already 
discover an exclusivist dynamic: it was originally a legal term that indicated rights connected to the possession of land and reserved for those settled in a specific community. In Switzerland this notion is preserved even today in the so-called Heimatort, or place of home, affirmed in every Swiss passport as the place you or your (paternal) family stem from-and to which you could return at any stage if you were destitute and be housed and fed and looked after. Today this is of practical irrelevancy in a time of social security systems independent of place and origin, but the fact that in Switzerland and for the Swiss it still carries considerable symbolic significance and emotional attachement is particularly telling.

So we can say that the notion of Heimat is and was from the beginning a nostalgic one: that a heightened sense of one's origins, of one's place develops in the moment of loss. "When does the urge to write about Heimat develop? In moments of conflict with it? When it is perceived as narrow and oppressive? When one is about to lose it? Or when one has lost it?" asks Rüdiger Görner (2007: 42), one of the many contemporary intellectuals who have revisited and interrogated this specific concept of place in recent times. The Heimat discourse is in large parts one of loss and alienation. The German writer Bernhard Schlink, internationally known as author of The Reader, expressed this very well in a recent essay entitled Heimat as Utopia: "Heimat is a utopia. One experiences it at its most intensive when one has gone away and when one is missing it: the real emotion regarding Heimat is Heimweh, the pain of longing for it [...]. Memories transform a place into Heimat, memories of something gone and lost, or even the longing for what is gone and lost, or even the longing for this longing. Heimat is a place not as what it is, but as what it is not" (Schlink, 2000: $32 \mathrm{f}$ ). In this sense it is the longing for lost origins and for a return to these origins that was also palpable in the earlier Novalis quotation. Is this a longing that weakens or grows stronger under the conditions of globalisation? 
If we think of loss of home or homeland, we think, in the first instance, of the experience of migration, voluntarily or forced, of being expelled. We conceptualise the loss of home principally as a movement in space - but it is of course and equally and in the first instance a movement in time. In one important sense we are all expelled from the place where we first developed a sense of belonging and orientation - our childhood. We have all been expelled from the real or imagined idyll of our childhood. The loss of Heimat should therefore be thought of as a temporal as much as a spatial dynamic - and one that affects each and every person. The great Marxist and idealist philosopher Ernst Bloch, in the last sentences of The Principle of Hope, offers precisely this strong interpretation of Heimat. Endowing the concept with utopian vigour and promise, he defines it as "something which shines into the childhood of all and in which no-one has yet been: homeland" (Bloch, 1986: 1376). Recent feminist studies (Ecker 1997; Boa and Palfreyman, 2000) have offered a convincing oedipal reading of this narrative of loss and longing - the painful and enduring separation from the cosiness and security of our place of origin, from its womb-like warmth, so to speak, a place, however, that can also become claustrophobic and trigger reflexes of flight and escape. Heimat is in this sense also an anti-utopia, a place of repression and fear: the critical literature of the $70 \mathrm{~s}$ and $80 \mathrm{~s}$ in the German-speaking world, and especially in Austria, has created a whole genre of Anti-Heimat writings that describe home and the place of origin as an oppressive, intolerant and suffocating environment that we need to cut loose from in order to develop a strong self and an identity of our own.

While this notion of home and place may carry mostly nostalgic or retrospective connotations, looking backwards towards a paradise lost or a prison escaped from, Ernst Bloch stressed its open and future-oriented potential, the sense of agency that arises out of rootedness and a strong sense of identity connected to place. Anthropologists 
and neurobiologists tell us about the fundamental importance of repetitions, routines and rituals for our sense of stability, security and happiness. In this sense home is the place where such routines are established and experienced. This does not necessarily have anything to do with cliches of a rural idyll, untouched by the rapid transformations of modernity - an idyll that exists hardly anywhere anymore, if it ever existed, and today is largely the product of the tourism industry. European ethnologists such as Ina Maria Greverius or Hermann Bausinger, who since the 1970s have argued for an active and positive notion of homeplace, one that is neither folkloristic nor exclusivist nor essentialist, have stressed the importance of two dimensions of locality and place that are decisive for our sense of identity: firstly, the notion of a defined locality where we feel familiar and safe; and, secondly, a link with tradition and history, a sense of continuity that exceeds and transcends the individual generation, a link between personal experience and memory and the cultural memory of a real or imagined community (cf. Greverius 1979; Bausinger 2002). The loss or absence of such certainties, routines and mental links to a community and its history in the maelstrom of mobile lives and liquid identities might indeed trigger considerable discontents and anxieties with consequences for our sense of confidence and agency.

However, the notion that the local territory is what enables and defines cultural identity and a sense of belonging forces a binary logic onto the discursive formation of identity, one which in the history of civilisation has proven deeply problematic and destructive, defining identity as it does via the dynamic of belonging and non-belonging, inclusion and exclusion, self and other. In the German context we have only to think of how easy it was for Nazi fascism to essentialise the notion of rootedness for their myth of blood and soil and to make it a centrepiece of their racist and expansionist ideologies (cf. Blickle 2002). But we do not need the Nazis in order 
to see the problematic of an identity politics that operates with the rhetoric of origin and belonging, of demarcation and othering. Sociopolitical research has shown that there is a strong correlation between a fixed concept of the home region that idealises images of harmony and homogeneity and xenophobic tendencies, in which migrants and new arrivals are seen as threatening agents of unwelcome and uncontrollable change. Marc Augé in his study of non-places argues that settled people feel easily threatened by migrants or nomadic lifestyles, as they remind them of the principal instability of their imagined securities (Augé, 1995: 119). Political examples for this dynamic are not hard to find. One has only to think of the 2014 elections to the European parliament which returned a strong group of xenophobic parliamentarians from all over Europe to Strasbourg: on the rise are nationalist and xenophobic parties who see the effects of globalisation as a threat and react with a political and cultural closing-in around perceived and postulated notions of origin, belonging and proclaimed homogeneity of cultural identity. In Switzerland, an example to which I will return, the Swiss People's Party (the strongest party with around $30 \%$ of the popular vote) deploys cliches of peaceful and homogenous communities embedded in an unspoilt nature for their isolationist policies. This party uses the instruments of direct democracy, which are nowhere as developed as in Switzerland, to reinforce a narrow and intolerant cultural model which underpins xenophobic politics. One has only to think of their won 2010 referendum on the banning of minarets as symbols of an alleged Islamic claim for dominance, or the successful 2014 initiative against mass immigration which forces the government to go against existing bilateral agreements with the EU by introducing quotas on the immigration of foreigners. If this tells us anything, then it is of the enduring, but deeply problematic, appeal of narratives of origin and belonging as a counter to the destabilising and threatening effects of globalisation. 
But we also need to look at this from the other side and re-evaluate the deterritorialising effects of globalisation mentioned at the beginning not primarily as a loss or a danger, but as a chance for a more flexible and dynamic notion of place. That is Arjun Appadurai's view in his influential study Modernity at Large on the cultural dimensions of globalization. He critiques the illusion of a "cultural bedrock, made up of a closed set of reproductive practices and untouched by rumours of the world at large" (1996: 63), which is no longer sustainable as „even the most localised of these worlds [...] have become inflected [...] by cosmopolitan scripts” (1996: 154). In 2003 Ronald Robertson coined the influential term 'glocalization' for this phenomenon, the intermeshing of global tendencies with local specifics, so that a new focus on the local, which we can observe in many contexts and in many cultures, does not stand in any simplistic opposition to the processes of globalisation, but is rather to be understood as a complementary process in which the local transforms by absorbing global influences, conflating them with regional traditions and cultural practices.

We also need to acknowledge as one effect of globalisation the growing importance of imagined communities in hi-tech communication networks: the revolutions in travel and information technologies mean that the homeplace which migrants are forced to leave is not so far away or unreachable as in the past, and that there is no longer any need for - for example - an 'American wake', a final farewell, which in Ireland had such a central place in the mythology of home. Return, temporary or for good, is now a distinct option and often part of the plan, and communication with home and within diasporic communities is constant and incessant: and not only diasporic identities rely on communication networks that are independent of locality and spatial closeness and do not need a shared territory to feel a sense of community or belonging. As Benedict Anderson demonstrated in his groundbreaking book 
Imagined Communities, the exponential growth in the late 18th and early 19th centuries in literacy and the book market, as well as the rise of newspapers and periodicals and a well-functioning postal service, were necessary prerequisites for the establishment of imagined national communities, a functioning public sphere and the building of a shared national identity. Today e-mail, skype, social networks, the internet, satellite TV and mobile phones have become engines of new diasporic communities and public spheres, which Shani (2011: 395) calls "digital diasporas". They have been central drivers for the creation of what Appadurai calls symbolic "mediascapes" und global "ethnoscapes" (1996: 48 ff.) of geographical mobility for the new transational, global imagined communities. How much physical presence, if any, is necessary to create and sustain a sense of community and belonging? This might not least be a generational question: many members of the digital diaspora, among them especially the digital natives of the 21st century, might feel more at home in the symbolic mediascapes and the imagined communities of cyberspace than in their actual physical location.

The importance of place for cultural and political identity is of course also highly culture-specific. It is historically of special importance for communities with traditionally lower rates of internal and external mobility and for societies like those in Europe, for whom the isomorphism of language, culture, ethnicity, political system and territory, the extremely influential notion that those who speak the same language and share history and culture should be united in one territory, was a powerful founding ideology of the nation state (Leerssen 2006; Kamusella 2009). Of course this strong link between place and identity has a very dark, exclusivist and violent side, as it was a fiction that historically found little correspondence anywhere in social and geographical reality and could only be enforced by displacing and expelling those who did not fit into this forced homogeneity. 
We also have to ask whether the modern cosmopolitan of today, who is constantly on the move and derives a sense of identity from precisely this outer and inner mobility, might feel particularly at home in what Marc Augé has famously, but somewhat misleadingly, called non-places: motorways, railway stations, hotels and, most importantly in a global age, airports - all transitory spaces that, according to Augé, ex negativo define place in hypermodernity. Augé calls them non-places as in his view they cannot be connected to locally and historically distinct experiences and memories and therefore cannot contribute to a sense of identity. But couldn't it be precisely, as Agnes Heller (1995) has argued, these non-places global homogeneity and interchangeability that create a sense of familiarity and home in modern nomadic subjects? In this sense their very quality as non-places could dialectically flip them into places that create familiarity and mark identity in a global age.

Overall the effects of globalisation and the debates around them counter the myths of origin and purity by highlighting the fact that cultures have always been connected and defined by processes of intercultural exchange and transcultural melange and that cultural hybridity has always been the norm and not the exception. As Edward Said puts it: "All cultures are involved in one another, none is single and pure, all are hybrid and heterogenous, extraordinarily differentiated and unmonolithic" (1993: XXIX). In this light the concept of place has to be critically revised against the essentialising myth of homogeneity and the defensive and exclusionary binary of inside and outside, of us and them, and developed into a new concept that embraces the transcultural richness of plural lifeworlds and multicultural identities. Following this line of argument, Tomlinson, Robertson and others see the active and conscious integration of local and global perspectives as characteristic of cultural identities in the age of globalisation. The movement between regions, countries, cultures and continents becomes more and more the norm, and this 
requires a new mental and cultural disposition which enables life in the in-between to be an active process in which disembedding and embedding belong together and become inseparable, and in which embedding is a cultural technique for creating a new sense of belonging. Heimat as choice and not as fate. Ulrich Beck in his study What is Globalisation? calls this positive mental disposition, which he sees as increasingly typical for the nomadic subjects of today, "place polygamy" (2000: $72 \mathrm{ff}$.), the ability to feel at home in more than one place. Similarly Agnes Heller (1995) contrasts geographic monogamy with geographic promiscuity, and sees the latter as a distinct and plausible mindset for our global age. These are curious terms, however, for at least two reasons. Firstly, they gender the locality invested with emotions of belonging by ascribing to it the female position. Secondly, and more importantly, the metaphors of polygamy and promiscuity have very strong negative normative connotations that actually work against the intentions and arguments of Beck and Heller: promiscuity is morally dubious and polygamy is illegal in most cultures. Disloyalty against one's place of origin or belonging as an act of infidelity or even criminality? Here the metaphors turn against their authors and their pluralistic argument and indicate perhaps how deep and enduring our mental and emotional fixations on traditional notions of place and belonging still are. Be that as it may, theoreticians of cultural hybridity such as Homi Bhaba (1994), Stuart Hall (1992) or Nestor Garcia Canclini (1995) have argued that cultural hybridity is the mental model that can best accommodate the challenges of globalisation and life in the third space as an empowering experience rather than as deficiency or even deviance. However, given that more than $75 \%$ of the world's population still lives entirely settled lives and never moves from the place they were born, we should heed the warning of Edward Said who cautioned against the tendency of modern writers and intellectuals projecting their own sense of dislocation 
as a universal condition of culture in a globalised world (Said 1984). The celebration of place polygamy and cultural hybridity is also in danger of romanticising exile and underrating and underplaying the difficulties and struggles which come with loss of place, search for a new Heimat and the processes of disembedding and reembedding, especially for the many millions of refugees and migrants who do not leave their homeland voluntarily.

These general observations, trends and figures come to life and can be concretised as individual experiences in life writing: autobiographical or semi-autobiographical narratives of Heimat and loss of same, of places and non-places, of processes of disembedding and re-embedding. Under the conditions of globalisation, inter- or transcultural literature, fictional or semi-fictional accounts of the loss of Heimat, whether temporal or spatial, of moves between cultures and of processes of glocalisation encode complex negotiations between the past and the present, between an old and a new Heimat, and can be read symptomatically and symbolically.

Two brief contemporary examples from Switzerland, encoding different backgrounds, genders and generational experiences, can serve as illustrations of the enduring power of place and Heimat under the conditions of globalisation and of the very different ways in which it can be negotiated. The first example is from Thomas Hürlimann, a settled and well-rooted Swiss author from the inner cantons - the geographical and symbolic centre of Switzerland. Hürlimann's biography is deeply enmeshed in Swiss history, as he is the son of a prominent politician. The second example is from Melinda Nadj Abonji, a migrant author who came to Switzerland at the age of five and from the very start wrote not in her native Hungarian tongue but in German. In 2010 she won both the German and the Swiss book prize with her highly acclaimed first novel Tauben fliegen auf (recently translated into English under the title Fly Away, Pigeon). Both authors put forward a strong and highly 
emotive sense of Heimat, but one that is neither uncritical nor naive. Hürlimann reflects on the temporal loss of Heimat from the perspective of someone who sees his homeplace radically changed and destabilised by the effects of globalisation, and who interprets this as a threat to the identities linked to place. Melinda Nadj Abonji, taking the in-between perspective of a migrant, writes about the spatial displacements of home and Heimat as transitory processes. She structures her novel as a narrative of painful loss of belonging to her place of origin and her cultural identity associated with it, and of equally difficult processes of embedding herself in an often alien and hostile Switzerland.

Switzerland is an interesting case of Heimat discourse in the germanophone world for a number of reasons. Unlike Germany it is not burdened with the racist and supremacist Nazi legacy of Blut und Boden, blood and soil, although it too did invoke strong tropes of belonging and cultural identity linked to place, landscape and history in its concept of Geistige Landesverteidigung - which could be translated as mental national defence - in order to mobilise resistance against Nazi Germany in the 1930s and 40s. Today, however, the right-wing policies of its strongest party take very open recourse to the conservative and essentialist aspects of Heimat discourse and instrumentalise this for an identity politics that legitimises their anti-immigration policies. Another aspect concerns Switzerland's political structures. Federalism and direct democracy are stronger and more constitutive for the political system and process than anywhere else, and in its 26 cantons the notions of self-government and direct democracy are very closely linked to the concept of locality and place. Many decisions are taken at local level and by the people via referenda, and allegiance to your village, town or canton is often either stronger than to the state and the nation or at least in constant rivalry with it. Thus Switzerland has embedded in its political structures and cultural 
identity a very strong concept of place. Economically however Switzerland is of course one of the most globalised economies in the world. Its unrivalled economic success as one of Europe's major exporters of high quality products and as one of the richest and most competitive societies in the world is entirely dependent on its globalised economic network of banks, businesses, financial institutions, pharmaceutical companies and high tech SMEs. The fact that Switzerland has (at 23\%) the highest proportion of non-nationals in Europe, but finds it very difficult to integrate these into its impressive political system of direct democracy, is indicative for both these trends. Switzerland thus embodies in a radical way a characteristic tension of the globalised world: its economic system is entirely globalised, whereas its political system is often claustrophobically localised.

Thomas Hürlimann, in a 2001 essay subtitled My Country in its Biggest Crisis, reads two of the three Swiss catastrophes of the autumn of that year, which dramatically shook and destroyed foundational Swiss myths and undermined Swiss identity in a fundamental way, as symbolic of these tensions. He starts off with the traumatic grounding of the national airline Swissair on 3 October 2001 - when the planes of the most prominent global symbol of Switzerland were unable to take off because the airline could not pay its fuel bills - followed by the airline's subsequent bankruptcy and humiliating sale to its German rival Lufthansa. Swissair was such a potent symbol as it encapsulated both sides: on the one hand it was a chief agent of worldwide networking and globalised mobility, while on the other it was a prime representative of such typical Swiss trademarks as high quality, luxury, solidity and reliability. Before the Swissair trauma, according to Hürlimann, the Swiss inhabitated

two Switzerlands: We lead a perfect double life, and we lead it in a way that normally only the insane can bring off [...], in two 
utterly different spaces at one and the same time. [...] We owned on the one hand a great, transcendental Switzerland - where we did our business-and on the other a small, concrete and manageable Switzerland - where we did our politics (Hürlimann, 2001: 10) [...] Switzerland developed into a global player ahead of time. Our watches, our psycho-pharmaceutical drugs, our chocolates conquered the global market [...] one state, two spaces. In the trust of Switzerland Inc. we were global capitalists, and in the 'Swiss Hut' (our term of praise for the country in songs) deeply-rooted confederates (Hürlimann, 2001: 12). [...] No, we did not go mad: at most we believed, just like the insane do, that we were the only normal ones (Hürlimann, 2001: 13).

Hürlimann goes on to use the second national catastrophe of that autumn (the third one being the catastrophic fire in the Gotthard-tunnel on 20 Oct.) to illustrate how these tensions dramatically erupted. On 27 September 2001 in the canton parliament of Hürlimann's hometown Zug, the capital of the small, affluent canton of the same name in the heart of Switzerland, a lone gunman ran amok and killed fourteen local politicians with a Swiss army assault rifle. This massacre, so out of place in a seemingly harmonious, slightly sleepy backwater in the Swiss Alps, was particularly shocking as it so radically disproved a core myth of the Swiss political system-namely, that federalist regionalism and direct democracy fostered and guaranteed a strong sense of belonging and identity which protected the Heimat from the dangers prevalent elsewhere in the outside world. The fact that the assault was carried out with a Swiss army rifle, which every adult male serving in the Swiss militia army has at home and which is seen as a central symbol of the strong identification of the populace with the political system and of the will to defend it, of course greatly enhanced the symbolism of this massacre. 
Hürlimann's analysis links the dreadful deed of a deranged man to the rapid changes his hometown underwent during the years of globalisation:

When I was in primary school and an altar boy, the small town by the lake lived in the familiar groove of the nineteenth century, and people were bourgeois, honest, stolid. Then it was decided to lower taxes, and as if by magic we found ourselves turned overnight into an international finance hub, a bay attracting financial sharks from all over the world. Without much having changed on the outside - geranium pots continued to hang from the railway station's platform roofs - the canton capital of just under 20,000 inhabitants was catapulted to the world's fourth-largest oil-trading place, and naturally one functioning according to other laws and speeds than those of the municipality with its parties, guilds and associations. One small town; two spaces; two epochs, and as the one worked ever more slowly and the other kept accelerating, they developed with and against each other an explosive power - in the truest sense of the word a ticking time bomb (Hürlimann, 2001: 14)

With the shooting in the local parliament the considerable pressures globalisation exerts on the local had arrived in the most dramatic fashion in Hürlimann's hometown in the heart of Switzerland. What had seemed to be an idyll was turned into a place of horror. The psychopath acts out and thus highlights the pathologies of the world around him. With this figure of thought, and in what is essentially a predominantly defensive and nostalgic narrative from someone who stayed at home and who registers and analyses and deplores the massive and seemingly uncontollable changes globalisation brings about, Hürlimann explores the mental and political topography of the schizophrenic place that Heimat has become for him under the conditions of globalisation. 
Melinda Nadj Abonji's largely autobiographical novel Fly Away, Pigeon narrates processes of disembedding and reembedding from the perspective of a migrant in a way that accentuates both an acute sense of loss, but also and in the end more importantly and lastingly a sense of agency in creating a new Heimat and in working towards an identity that accepts her hybrid or transitory position and draws inspiration and strength from it. Her first-person narrator Ildiko Kocsis moved, like herself, at the age of five from the Vojvodina in Serbia (which was then still a part of Yugoslavia), where she belonged to the Hungarian-speaking minority, to Switzerland. She tells the story of her family, who ultimately succeed in Zurich by taking over a cafe in a prominent location in an affluent village by Lake Zurich at the so-called Gold Coast. The Kocsis even acquire Swiss citizenship as a prominent marker of their success, but their story is described as a long and difficult process, characterised by enormous pressures to conform and marked by countless humiliations and experiences of condescending attitudes and outright hostility and xenophobia.

The theme of Heimat is very prominent in the novel from the first page on. It opens with a highly typical and symbolic feature of transitory lives lived between two cultures: the summer return to the village of Ildiko's early childhood years. In the centre of this return is a big Chevrolet, a car from the motherland of mobility and globalisation, a symbol of her family's transitory situation and a potent marker of both their economic success and their growing estrangement from their place of origin. This annual return is on the whole highly ambivalent, which is accentuated by the fact that the first-person narrator wants to keep the image of her early childhood, her original Heimat, intact and immune to the changes that her own life is so exposed to: "I hope everything is as it used to be, because when I return to the place of my early childhood I fear nothing more than change" (Abonji, 2010: 13). The author thus opens up 
with exactly the tensions we have identified above between notions of Heimat as a place of familiarity and reliability and the dynamics of mobility and change:

The soft singsong of my grandmother, the nightly croaking of frogs, the pigs when they squint with their piggy eyes, the excited cackling of a chicken before it is slaughtered, the damask violets and apricot roses, coarse swearing, the merciless summer sun, along with the smell of steamed onions, my strict uncle Moric, who all of a sudden gets up and dances. The atmosphere of my childhood. This is what I answered after thinking about it for a long time, when years later a friend asked me what Heimat meant for me. (Abonji, 2010: 19)

Such images of Heimat are that of a rural idyll of the nineteenth century: an intact, close - knit community, close to nature, rough but loving. As the novel unfolds, these nostalgic and sentimental childhood memories, frozen in time by loss and estrangement and the hope that nothing could change them, are shown to be illusions. The laconic title of the first chapter, 'Tito's Summer' (Abonji, 2010: 5), already shows this by juxtaposing change and stability, politics and nature, threat and promise, the world of the adults and the world of the children. It reveals the Heimat idyll as a naive perspective and a sentimental construction. Only from the perspective of the child and in childhood memories is the narrator's world idyllic. It becomes later visible to the adolescent heroine that it is functioning according to a much more violent logic of inclusion and exclusion than the xenophobia the family experiences in Switzerland - especially for women seeking some form of a self-determined life.

The second chapter is situated in Switzerland and serves as a counterpart. It begins with the moment of triumph after 13 years of hard work and painful humiliations: the taking over of the cafe 
in a prime location and the granting of Swiss citizenship. The story of Ildiko's parents is one of becoming Swiss by dint of hard work, keeping your head down and over-identification with Swiss virtues such as cleanliness, orderliness, punctuality and politeness. But for all these efforts the Kocsis remain forever identifiable as Papierschweizer, 'Swiss' on paper only, marked out not least by their insufficient command of Swiss German - a prime marker of identity but, without a written grammar and a dictionary, a local dialect so much harder to acquire than standard German. The heroine of the novel is part of this, helping in the family business, dutifully working in the cafe as a proper Serviertochter (the Swiss term translates aptly as 'service daughter'), but during the course of the novel increasingly rebels against such docile overassimilation. Ultimately it is the Balkan wars of the mid-1990s following the break up of Yugoslavia that demonstrate in the most brutal way possible that there is no return to the former childhood worlds and that a life has to be carved out in Switzerland, even though the repercussions of the war spill dramatically over into the secluded world of the Swiss village. It is of course indicative in this context that this war was waged in the name of precisely the exclusivist, racist and essentialising notions of Heimat that are in parts a defensive backlash against the forces of globalisation and also feed Swiss hostility towards foreigners and immigrants.

In its narrative structure, with chapters alternating between the Serbian and Swiss locations, the novel enacts the real and mental topography of the migrants' movements between cultures, the painful processes of loss of Heimat, but also the creation of a new sense of belonging. The narrator achieves this by rejecting the docility and conformism of her parents and, in a generation-specific form of assimilation, by joining alternative and protest movements in Zurich like her Swiss friends thus opening up spaces for the negotiation of an open identity as a woman that would have been unthinkable in 
her Serbian Heimat. Also as a student of history and, in the closing chapter, a writer who chooses the language of her new Heimat, the first-person narrator of this autobiographical novel demonstrates the transitory experiences of place polygamy and of disembedding and reembedding as open and active processes. It is a considerable strength of this remarkable novel that it demonstrates in a highly differentiated manner and in an emotive language the potential of transcultural literature to make available to its readers the pains, challenges and opportunities of such hybrid identities.

So what, in conclusion, is the status of place and belonging in the age of globalisation? It certainly continues to be of fundamental relevance, but it can be negotiated in very different ways that impact hugely on cultural identity, sense of self and identity politics, at the level both of the individual and of communities. In an era of hypermobility, the power of place and belonging is weakening, yet must not be underestimated. On the political front it can, as a defensive reaction against the dynamics of globalisation, negatively fuel the rise of nationalisms and fundamentalisms, and remobilise xenophobic and essentialist dynamics of exclusion. On the other hand, and more positively, connection and allegiance to place and community, their concerns and their future, can, when confronted and embraced in an active, inclusive and open manner, be a powerful source of identity and agency. In this sense our ongoing quest for the next frontier might be driven by the ultimately illusionary, but for precisely that reason very powerful, desire to come home. Which brings us back to the beginning, to the Romantic poet Novalis: “'Where are we going to?' 'Forever homewards.” 


\section{References}

Abonji, M. N. (2010). Tauben fliegen auf. Salzburg, Wien: Jung und Jung.

Anderson, B. (1983). Imagined Communities: Reflections on the Origin and Spread of Nationalism. London: Verso.

Appadurai, A. (1996). Modernity at Large: Cultural Dimensions of Globalization.

Minneapolis, London: University of Minnesota Press.

Augé, M. (1995). Non-places: Introduction to an Anthropology of Supermodernity. London: Verso.

Bhaba, H. (1994). The Location of Culture. New York: Routledge.

Bauman, Z. (2000). Liquid Modernity. Cambridge: Polity.

Bausinger, H. (2002). "Globalisierung und Heimat: Ein Essay". In: G. Ueding (ed.), Fremde Nähe. Auf Seitenwegen zum Ziel. Tübingen: Klöpfer und Meyer in der DVA, pp. 11-34.

Beck, U. (2000). What is Globalization?. Cambridge: Polity Press.

Blickle, P. (2002). Heimat: A Critical Theory of the German Idea of Homeland. Rochester N.Y., Woodbrigde: Camden House.

Bloch, E. (1986). The Principle of Hope. Vol. 3. Oxford: Blackwell.

Boa, E.; Palfreyman, R. (2000). Heimat. A German Dream: Regional Loyalties and National Identity in German Culture 1890-1990. Oxford: Oxford University Press.

Böhme, H. (2005). "Einleitung Sektion IV: Die Grenzen und das Fremde". In: H. Böhme (ed.), Topographien der Literatur: Deutsche Literatur im transnationalen Kontext. Germanistische Symposien. Berichtsbände 27 Stuttgart. Weimar: Metzler, pp. 597-602.

Canclini, N. G. (1995). Hybrid Cultures: Strategies for Entering and Leaving Modernity. Minneapolis: University of Minnesota Press.

Ecker, G. (ed.) (1997). Kein Land in Sicht: Heimat - weiblich? München: Fink 1997.

Elliott, A. (2014). Concepts of the Self. 3rd edition. Revised and updated. Cambridge: Polity.

Giddens, A. (1991). Consequences of Modernity. Cambridge: Polity.

Görner, R. (2007). "Dichterheimat. Friedrich Hölderlin, Die "Heimat'“". In: Reich-Ranicki, M. (ed.), Frankfurter Anthologie. Gedichte und Interpretationen. Vol 31. Frankfurt/M.: Insel, pp. 41-44.

Greverius, I. M. (1979). Auf der Suche nach Heimat. München: Beck.

Hall, S. (1992). "The Question of Cultural Identity". In: Hall, S.; Held, D.; McGrew A. (eds), Modernity and Its Futures. Cambridge: Polity, pp. 274-316.

Hardenberg, F. v. [Novalis] (1987). Heinrich von Ofterdingen. Stuttgart: Reclam.

Heller, A. (1995). "Where are we at home?". In: Thesis Eleven. Critical Theory and Historical Sociology 41, pp. 1-18. 
Hürlimann, T. (2002). "Himmelsöhi, hilf! Mein Land in seiner größten Krise". In: T. Hürlimann, Himmelsöhi, hilf! Über die Schweiz und andere Nester. Zürich: Ammann, pp. 9-22.

Kamusella, T. (2009). The Politics of Language and Nationalism in Modern Central Europe. Basingstoke: Palgrave.

Leerssen, J. (2006). National Thought in Europe: A Cultural History. Amsterdam: Rodopi.

Morley, D. (2000). Home Territories: Media, Mobility and Identity. London: Routledge.

Robertson, R. (1995). "Glocalization: Time - Space and Homogeneity - Heterogeneity". In: Featherstone, M.; Lash, S.; Robertson, R. (1995). Global Modernities. London: Sage, pp.25-45.

Said, E. (1984). "The Mind of Winter. Reflections on Life". In: Exile Harper's Magazine, September, pp. 49-55.

Said, E. (1993). Culture and Imperialism. New York: Alfred A. Knopf.

Schlink, B. (2000). Heimat als Utopie. Frankfurt/M.: Suhrkamp.

Shani, G. (2011). "Identity-politics in the global age". In: Elliott, A. (ed.). Routledge Handbook of Identity Studies (pp. 380-396). New York: Routledge.

Tomlinson, J. (2007). “Cultural Globalization”. In: Ritzer, G. (ed.). The Blackwell Companion to Globalization. Oxford: Blackwell. 